Вісник Львівського університету. Серія філос.-політолог. студіï. 2021. Випуск 36, с. 109-115

Visnyk of the Lviv University. Series Philos.-Political Studies. Issue 36, p. 109-115

UDC 165.9

DOI https://doi.org/10.30970/PPS.2021.36.13

\title{
THE PROBLEM OF UNITY OF KNOWLEDGE: FROM THE IDEA OF UNIFICATION TO THE PROCESS OF INTEGRATION
}

\author{
Bohdana Manchul \\ Yuriy Fedkovych Chernivtsi National University, \\ Faculty of Philology, Department of Philosophy and Cultural Studies \\ Kotsiubynsky str., 2, 58012, Chernivtsi, Ukraine
}

In the early 20th century, the need to revise the purpose and structure of scientific knowledge and understanding became one of the key problems for philosophers and scientists. Many models of holistic knowledge were proposed. In the 1920s and 1930s, representatives of the Vienna Circle developed a system of unified science with reductionism as the leading research method. It was based on a simple logical scheme of reducing one science to another according to the principles of natural levels of organization. However, reductionism in positivistic interpretation was strongly criticized. In the mid-20th century, instead of the question "How can scientific knowledge be unified?" the emphasis was set on the question "Is unification a key to understanding what a scientific explanation is?". Thus, M. Fridman and F. Kitcher proposed a model of explanatory unity of knowledge, according to which the principle of unification is directly related to understanding, and the unity of scientific theory is determined by how useful it is in creating a holistic systematized argument. In the late 20th - early 21 st centuries, the idea of the unity of knowledge was replaced by the process of disciplinary integration with a complex structure and typology. In particular, there are diachronic and synchronic, integrative and interactive, intra-scientific and extra-scientific levels of knowledge integration. In particular, multi and crossdisciplinarity represent the temporary interaction between scientific disciplines; inter and transdisciplinarity are considered to be more stable types of knowledge synthesis; non, post, and antidisciplinarity are common for integration of knowledge outside of science. The current interpretation of scientific integration focuses more on how to systematize and integrate existing knowledge, what methodology to use in research, how to unify terms, etc., but it does not give a clear answer as to whether such an approach provides new knowledge.

Key words: philosophy of science, unity of knowledge, unified science, scientific explanation, scientific understanding, scientific research, scientific theory, integration of knowledge, reductionism.

Articulation of the issue. The interconnection of disciplinary boundaries is of great interest among philosophers, psychologists, sociologists, cognitivists, and historians of science. The idea of unity of knowledge is not new. The history of mankind is an example of the fact that most of the cultures, reflecting on art and literature, nature and man, usually rely on the idea of holistic knowledge, which is often due to the influence of philosophical and religious thought. Nevertheless, the disciplinary structure of science became a leading trend in the last four centuries of its history. However, the need to reconsider the purpose and structure of scientific knowledge and to understand how scientific explanation was possible became one of the key issues for both philosophers and scientists.

Current scientific researches and issues analysis. The concept of unity of knowledge has been studied in numerous works, among them there should be mentioned those by G. Tanzella-Nitti, T. Tahko, E. Sober, J. Cat. It is worth mentioning R. Carnap's, O. Neurath's interpretation of reductionism, C. Hempel's deductive-nomological method, P. Oppenheim's and H. Putnam's ontological model of unity of science, F. Kitcher's and M. Fridman's epistemic model of explanatory unity, T. Grantham's and V. Gijsbers' conceptualization of disunity of science, J. Klein's and J. Moran's analysis of the rise of disciplinary integration.

(C) B. Manchul, 2021 
Unresolved problem analysis. In the 19th century, positivists have set a rather ambitious goal of understanding what was the foundation of scientific knowledge. This process was inevitable, taking into account the breakthrough in research and discoveries which science (especially physics) was experiencing at that time. Early positivists have developed a disciplinary hierarchy from the most general disciplines about simple phenomena to highly specialized areas about complicated phenomena. Taking into account the variety of research approaches, positivists saw the problem in the possibility of creating a single methodological standard. Their idea was to develop a fundamental system that would enable the integration of scientific knowledge under the general name "The Unified Science". This term has gained popularity not only among philosophers but also among scholars. Later this process has gone through a variety of transformations: from explanatory unification to pluralism, and, finally, to disciplinary integration. The question that still causes a lot of discussions is whether unified and integrated knowledge can create a holistic scientific picture of the world.

Research results presentation. In the 20th century, the call for unified knowledge has been made in a circle of scientists who professed the idea that science can use a holistic approach precisely because nature per se is unified. In the 20th century, the most important metaphysical questions had been posed by scientists, not by philosophers. Many have tried to focus on the relationship between different forms of knowledge, they opened new scientific horizons and wanted to offer a corresponding philosophical interpretation of their results. Even those contemporary scientists who were critical about spiritual and transcendent phenomena have not been able to avoid facing problems that are relevant also from a humanistic, not only scientific, point of view [1]. The rapid progress of science (especially natural sciences) violated the question of how the revolutionary discoveries of natural laws directly affect humans, their values, and spiritual experience and how to organize knowledge so that the integral picture of everything can be formed. A call to coordinate scientific and social activities through rational planning and promotion of the idea of a single science as a driving force of human civilization and technological progress became significantly loud. Unified knowledge remained a leading scientific ideal. Its goal was to emphasize that existing theories showed that both independent facts and phenomena could be united in a single scientific frame.

In the philosophy of science, the idea of unified knowledge was promoted by logical positivism (later known as logical empiricism), emphasizing the compulsory conduct of a clear distinction between science and metaphysics and removing the latest from the system of unified knowledge. The Vienna Circle became a peculiar center for the development of unification guidelines in the 1920s-1930s. They saw their goal in deprivation of science from metaphysical impurities and in the transition from fragmentary knowledge to the unified model. To achieve this, they focused on the role of logical ties in scientific knowledge.

From the very beginning, the unity of knowledge was considered as a methodological problem, therefore, its solution was seen in the attempt to develop a universal scientific method. The first and, probably, the most famous method was reductionism, which performed a double function: it acted as the unity of the observational and explanatory principles of science. The effectiveness of reductionism depended on the level of communication between the theories. It was based on reducing one science to another on the principle of natural levels of the organization. However, the problem that caused serious discussions was the use of reductionism in the study of such issues as organic processes and human consciousness. In the late 20th century, most philosophers of science agreed that reductionism in such a radical form was false.

Logical positivists singled out three key elements to the embodiment of the idea of unified science. Firstly, it was necessary to arrange a scientific language. The idea was to reduce all 
scientific terms to basic statements, or rather - to the physical scientific language. Secondly, it was necessary to create a single system of scientific laws. The standards of such laws were considered those that were formulated by physicists. And thirdly, it was necessary to unify scientific methods. This meant that the procedures for checking hypothetical statements in various fields of scientific knowledge should be the same or as similar as possible. The science that would have performed a certain methodological standard was physics.

Thus, reflecting on the possibility of building a unified scientific knowledge, the two leading ideas were formed within the Vienna circle. Initially, R. Carnap proposed to overcome the gap between different disciplines and objects of their research, considering that all science was based on personal experience that constructed the external world. An alternative proposal for unification was offered by C. Hempel, who argued that the structure of experience was objective and could be investigated empirically [2]. In 1936, O. Neurath launched the Institute of Unified Knowledge and became a co-editor (along with R. Carnap) of the "International Encyclopedia of Unified Science" (1938-1940). Its task, as defined by the philosopher, was to integrate scientific disciplines, to combine them so that the benefits of one became the benefits of another [3, p. 24]. At the same time, R. Carnap focused on the possibility to identify and unite all scientific concepts into a single system based on several fundamental concepts. Consequently, R. Carnap discovered a new form of strong reductionism, C. Hempel developed a deductive-nomological model of explanation, and $\mathrm{O}$. Neurath adhered to the problem of the unity of science [4].

In 1958, P. Oppenheim and H. Putnam redirected the discussion toward interpreting science as a reductive unity of concepts and laws. "The unity of science in the strongest sense is realized if the laws of science are not only reduced to the laws of some discipline, but the laws of this discipline in some intuitive sense are "unified" or "connected" [5, p. 4]. The authors considered the unity of science as an established empirical hypothesis, supported by evidence of actual scientific practice which was based on the reflected unity of nature [5, p. 16-27]. However, such a vision of scientific unity was criticized by many philosophers. In particular, H. Putnam in his late writings found a lot of gaps in his theory. He analyzed the place and importance of unification in scientific explanation and criticizes reductionism for being unable to become a foundation for the integration [6, p. 207].

Both logical empiricism and Oppenheim-Putnam's hypothesis are examples of the ontological model of unity of knowledge. There is also an epistemic (pragmatic) model of unity of knowledge. The difference between the two is that the first considers the unity of knowledge as the maximum effectiveness of knowledge, while the second one-as a real unity of diversity. The ontological approach determines which part of a separate explanation can perform the function of the unification: only those phenomena that are caused by a joint explanatory factor are taken into account. The pragmatic approach calls for an explanation that contains a variety of phenomena [7, p. 221].

Consequently, reflections and discussions on the capacity of a unified science had changed. Instead of the question, "How is it be possible to unify scientific knowledge?" philosophers of science focused on the question "Is the unification a key to understanding what a scientific explanation is?". In particular, it was popular among the supporters of the epistemic-pragmatic model of the unity of scientific knowledge, among the most famous representatives of which were M. Fridman and F. Kitcher. Their idea was that an explanation was construed in terms of deductive derivation. Some phenomena were deduced from a unifying premises or by using an explanatory pattern from a unifying set. The premises are considered to be the most general, fundamental, and explanatory if they are averted immediately or via a chain of explanatory deductions [8, p. 395]. Therefore, a causal relationship is derived from an explanation. The principle of unification is directly related to understanding, and the unity of the theory is determined by how it is 
useful in creating a holistic systematized argument. Therefore, an understanding is possible only in a certain form of unification, and the theories can only be combined with the criterion of integrity [9]. At the same time, M. Fridman's program idea was that the explanation was reduced to a small number of independently acceptable laws. Those laws that are issued independently and not related to others are the consequences of more fundamental laws [10, p. 271-272].

However, such a view of unification as an explanation has certain disadvantages. Firstly, the pragmatic approach determines the success of unification only when it gives a positive result, namely, a strong argument. However, the impossibility of creating such an argument may indicate disadvantages or weaknesses of both the theory and arguments in its favor, which also promotes scientific progress. Secondly, it is not convincing that the explanation of two or more events must necessarily be united by the same law. There are many examples that support such idea (especially in physics), however, there are examples when the existence of common features of the phenomena does not guarantee that they are subjected to the same laws. And thirdly, hypotheses that can explain two or more phenomena are considered epistemically better than hypotheses that cannot do this. Although unifying explanations have a greater probability, they are not necessarily true.

By integrating discoveries into the system of existing theories, scientists deepen theoretical ties within a certain theory and increase the level of theoretical integration. When a new explanation corresponds to the existing theory the explanatory force of the latter increases significantly. This means that it can be applied to a greater number of issues and problems associated with the subject being studied. Therefore, the idea of unified knowledge was popular because the involvement of unification in the heuristic process was one of the potential strategies for the progress of scientific theories.

It became clear that reductionism was unable to fulfill the function of building a model which would lead to the unification of science. Therefore, M. Natan's question was quite logical: "If the reduction is neither necessary nor sufficient for unification, what does it mean for two branches of science to be "unified"? [11, p. 166]. In the late 20th century, there have been attempts to answer this question by analyzing the theory of disciplinary integration. At first, it was considered at the level of construction of common theories. For example, H. Kinkeid determined the integrated inter-level theory as a higher manifestation of possible disciplinary interaction [12]. T. Grantham distinguished two categories: theoretical (conceptual, ontological, and explanatory) and practical (heuristic, and methodological) interconnections [13]. V. Gijsbers analyzed three approaches that dominated the scientific community regarding the possibility of integrated knowledge: one method of knowledge has an advantage over the rest; various explanations of a certain process are combined into one and it has an advantage over the rest of the methods; various approaches in the process of scientific research make their contribution to the overall result, but work separately [14]. Tendencies in scientific research show that neither of these approaches is dominant.

Most researchers of integration of scientific knowledge agree that in order for this process to succeed it has to fulfill particular conditions. Firstly, integration must contribute to scientific progress, to act as a motivating element to new discoveries or to rethinking the old ones. Secondly, it is necessary to develop general criteria for identifying various stages of synthesis and comparison of the theoretical and methodological unification between the branches of science. Thirdly, the synthesis of knowledge as an early form of integration begins as soon as there is a new problem that requires an integrative basis, and the degree of unification increases proportionally to the number and significance of the unknown and its explanations. Since there is no limit to the number of problems that can be explored, therefore, a maximum level of knowledge integration is impossible [11, p. 178]. Fourthly, integration is possible in ad hoc mode, when a separate scientific field has resources to respond to internal disciplinary issues, except for individual cases where disciplinary resources are not enough and there is a need for cooperation. 
Integration processes have a rather complicated and ambiguous classification. One of the classifications that consider the genealogical and historical nature of disciplines consists of diachronic and synchronic approaches. The first examines the integration in the historical context of the development of science. On the other hand, the synchronic approach considers integration not historically, but at a certain moment of its development. Thus, the two types of scientific synthesis can be distinguished: interactive and integrative. The interactive type is the temporary interaction between scientific disciplines. There are fields like multidisciplinarity (cooperation, in which a certain complex problem is simultaneously studied by several disciplines without the harmonization of research methods, terms, and subsequent prospects of joint work) and crossdisciplinarity (the use of methods of one discipline to study another) where such interactions occur on the same level. Therefore, this type of integration is also known as horizontal. The integrative type is determined by more stable interaction, as it is in interdisciplinarity (transferring of methods from one discipline to another discipline or combining methods of various disciplines to create one for the study of phenomena that are not fixed for some specific discipline) and transdisciplinarity (use of scientific methods in the study of complex systems that go beyond disciplinary science). It builds a certain hierarchy of disciplines that are involved in this process, so it is known as vertical. Various types of disciplinary integration are not mutually exclusive, but can function simultaneously. The second level of classification is a sphere of distribution of integration processes. It is possible to distinguish intra-scientific integration (multi, cross, interdisciplinarity); integration of scientific and non-scientific knowledge (trans, para, hyper, metadisciplinarity); integration of knowledge outside of science (non, post, antidisciplinarity). And the third level of classification is interdisciplinary integration. It can occur within the natural and socio-humanitarian disciplines (social psychology, biochemistry); between natural and socio-humanitarian disciplines (bioethics, economic geography, mathematical linguistics). And the fourth level is the interaction between scientific and beyond scientific (esoteric) knowledge [15, p. 9-10].

In the early $21^{\text {st }}$ century, the idea of the unity of science and, even, the integration of science is being reconsidered. The integrative approach is used by modern science to research and solve many phenomena, however, there is no clear understanding of how exactly it happens. In addition, there are still discussions about the heuristic potential of knowledge integration [16]. The current interpretation of scientific integration focuses more on how to systematize and integrate existing knowledge, what methodology to use in scientific research, how to unify terms, etc., but it does not provide a clear answer to whether such an approach produces new knowledge.

Conclusion. The issue of unification and integration of knowledge remains relevant both for science and philosophy. For science, it is important in terms of heuristic, methodological, instrumental, technical, and terminological potential. While philosophers are interested in metaphysical, epistemological, teleological, and normative aspects of this process, as well as in rethinking of concepts such as a "scientific explanation" and "scientific understanding". Historical analysis indicates that even discussing the possibilities of such processes helps to understand how the criteria of science change, what are its strong and weak methodological sides, which communicative capabilities modern scientific disciplines have, and how they affect a scientific research. It is also important to understand how the integration of knowledge changes modern education, which response to these processes in a much faster and creative way than science. At this stage of the development of science, the search for the middle way between the processes of disciplinary and methodological isolation and scientific integration dominates. Disciplinary integration parity is likely to be maintained because the research problem is formulated by a particular discipline or disciplines, and if it cannot or does not want to solve it on its own, attempts are made to involve other methods and resources (usually interdisciplinary). If a cer- 
tain discipline can independently answer the question, then the need for knowledge integration disappears. Therefore, the integration of knowledge is possible only with the heuristic methodological crisis. On the other hand, an attempt (although unsuccessful) to unify knowledge is not caused by the need for a separate discipline, but a more global goal - to build a single universal scientific picture of the world.

\section{References}

1. Tanzella-Nitti G. Unity of Knowledge. Interdisciplinary Encyclopedia of Religion and Science. DOI: 10.17421/2037-2329-2002-GT-8.

2. Bechtel W., Hamilton A. Reduction, Integration, and the Unity of Science: Natural, Behavioral, and Social Sciences and the Humanities. Philosophyof Science: Focal Issues (Volume 1 of the Handbook of the Philosophy of Science). DOI: 10.1016/B978-044451548-3/50009-4.

3. Neurath O. Unified Science as Encyclopedic Integration. International Encyclopedia of Unified Science. Chicago. 1938. Vol. 1, No, 1. P. 1-27. URL: https://books.google.com.ua/ books?hl=en\&lr=\&id=hf0Ar62uA34C\&oi=fnd\&pg=PA309\&ots=Q3UIs67175\&sig= 8JU45IeUgUIzAwvy9svchuEwO-g\&redir $\mathrm{esc}=\mathrm{y} \# \mathrm{v}=$ onepage $\& \mathrm{q} \& \mathrm{f}=$ false (Last accessed: 14.04.2021).

4. Tahko T. Unity of Science (Elements in the Philosophy of Science). Cambridge : Cambridge University Press. 2021. 80 p. DOI: 10.1017/9781108581417.

5. Oppenheim P., Putnam H. The Unity of Science as a Working Hypothesis. Concepts, Theories, and the Mind-Body Problem. Minneapolis : University of Minnesota Press. 1958. P. 3-36. URL: https://conservancy.umn.edu/ handle/ 11299/184622 (Last accessed: 25.04.2021).

6. Sober E. Two Uses of Unification. The Vienna Circle and Logical Empiricism. Dordrecht : Kluwer. 2003. P. 205-216. DOI: 10.1007/0-306-48214-2 17.

7. Hindriks F. Explanatory Unification in Experimental Philosophy: Let's Keep It Real. Review of Philosophy and Psychology. 2019. No. 10. P. 219-242. DOI: 10.1007/s13164-018-0397-0.

8. Breitenbach A., Choi Y. Pluralism and the Unity of Science. The Monist. 2017. No. 100 (3). P. 391-405. DOI: 10.1093/monist/onx017.

9. Kitcher P. Explanatory Unification. Philosophy of Science. 1981. Vol. 48, No 4. P. 507-531. DOI: $10.1086 / 289019$.

10. Psillos S. Causation and Explanation. Montreal : McGill-Queen's University Press. 2002. 324 p. URL: http://joelvelasco.net/teaching/5330(fall2013)/psillos-causationexplanationbookHume.pdf (Last accessed: 21.05.2021).

11. Nathan M. Unificatory Explanation. British Journal for the Philosophy of Science. 2017. Vol. 68, No. 1. P. 163-186. DOI: 10.1093/bjps/axv022.

12. Kincaid H. Molecular Biology and the Unity of Science. Philosophy of Science. 1990. Vol. 57, No. 4. P. 575-593. URL: http://jstor.org/stable/187762 (Last accessed: 31.05.2021).

13. Grantham T. Conceptualizing the (Dis)Unity of Science. Philosophy of Science. 2004. Vol. 71, No. 2. P. 133-155. DOI: 10.1086/383008.

14. Gijsbers V. Explanatory Pluralism and the (Dis)Unity of Science: The Argument from Incompatible Counterfactual Consequences. Front Psychiatry. 2016. Vol. 7, No. 32. DOI: $10.3389 /$ fpsyt.2016.00032.

15. Манчул Б.В. Інтегративні тенденції в науці: потенціал і форми актуалізації : автореф. дис. на здобуття наук. ступеня канд. філос. наук : 09.00.09. Чернівці, 2010. 22 с.

16. Kao M. Unification Beyond Justification: A Strategy for Theory Development. Synthese. 2019. No. 196. P. 3263-3278. DOI: 10.1007/s11229-017-1515-8. 


\title{
ПРОБЛЕМА ЄДНОСТІ ЗНАННЯ: ВІД ІДЕЇ УНІФІКАЦЇ̈ ДО ПРОЦЕСУ ІНТЕГРАЦІї
}

\author{
Богдана Манчул \\ Чернівецький національний університет імені Юрія Федьковича, \\ філологічний факультет, кафедра філософії та культурологї \\ вул. Кочьюбинського 2, 58012, м. Чернівиі, Україна
}

На початку XX століття необхідність переглянути мету і структуру наукового знання та зрозуміти, як можливе наукове пояснення, стала однією із ключових як серед філософів, так і серед учених. Було запропоновано чимало моделей побудови цілісного знання. У 1920-1930-х рр. представники Віденського гуртка розробили систему уніфікованої науки, в основі якої провідну функцію виконував метод редукціонізму. Він базувався на простій логічній схемі зведення однісї науки до іншої за принципом природних рівнів організації. Однак редукціонізм у позитивістському тлумаченні зазнав серйозної критики. У другій половині XX століття замість питання «Як можна уніфікувати наукове знання?» наголос був зроблений на питанні «Чи є об’єднання ключовим для розуміння того, що таке наукове пояснення?». Тому М. Фрідманом та Ф. Кітчером була запропонована модель пояснювальної єдності знання, згідно з якою принцип уніфікації був безпосередньо пов'язаний із розумінням, а єдність наукової теорії визначалася тим, наскільки вона корисна у створенні цілісного систематизованого аргументу. Наприкінці XX - на початку XXI століття ідея єдності знання була замінена на його інтеграцію. Цей процес має доволі складну структуру та типологію. Виокремлюють діахронічний та синхронічний, інтегративний та інтерактивний, внутрішньонауковий та позанауковий рівні інтеграції знання. Зокрема, мульти- та міждисциплінарність являють собою тимчасову взаємодію між науковими дисциплінами; інтер- та трансдисциплінарність вважаються більш стійкими типами синтезу знань; не-, пост- та антидисциплінарність $є$ поширеними для інтеграції знань поза наукою. Сучасна інтерпретація наукової інтеграції більше зосереджується на тому, як систематизувати та інтегрувати наявне знання, яку методологію використовувати в наукових дослідженнях, як уніфікувати терміни тощо, однак вона не дає чіткої відповіді на те, чи виробляє такий підхід нові знання.

Ключові слова: філософія науки, єдність знання, уніфікована наука, наукове пояснення, наукове розуміння, наукове дослідження, наукова теорія, інтеграція знання, редукціонізм. 